\title{
Trends of phytoplankton characteristics and their communities in pre- and post-liming time in Lake Orta (1984-1998)
}

\author{
Giuseppe MORABITO, Delio RUGGIU and Pierisa PANZANI \\ C.N.R. Istituto Italiano di Idrobiologia, L.go Tonolli 50, 28922 Pallanza, Italy
}

\begin{abstract}
This paper is an assessment of the changing properties of Lake Orta phytoplankton in the period 1984-1998, which includes the large-scale liming carried out in the lake in 1989 and 1990. The phytoplankton is analysed first in its general properties (abundance, biovolume, chlorophyll-a concentration, average cell size, diversity) by means of time courses of the mentioned variables based on monthly data through the entire period, and by correlations between the same variables. Moreover, through clustering techniques, the evolution of the species composition has been studied, showing the gradual decrease of chlorophytes after the liming and the noticeable increase of the diatom population, both as biovolume and diversity. Although the assemblage of the dominant species still mirrors the presence of some residual toxic compounds into the lake water, in the most recent period the evolution of the algal populations showed a clear trend towards a species assemblage more similar to those observed in the other deep italian subalpine lakes. After the improving of the chemical environment, the main abiotic factor that in the next years could play a major role in modifying the species assemblage is probably the phosphorus supply, whose in-lake concentration is low, despite the high annual load from the basin. A better understanding of the mechanisms underlying the phosphorus dynamics represent the basis to make reliable hypotheses about the future evolution of the phytoplankton assemblage.
\end{abstract}

Key words: long-term study, phytoplankton community evolution, diversity, liming

\section{INTRODUCTION}

Only scanty information is available on phytoplankton composition in Lake Orta for the time preceding the major pollution event in 1926. However, together with other information (zooplankton, fish), it demonstrates that the lake was biologically quite similar to the other deep, oligotrophic subalpine lakes in Italy. As for the algae, the communities were rich and diversified (Parona 1880; Bonardi 1885; Giaj-Levra 1925), with 154 diatom species recorded before the pollution.

The algae were extirpated by the copper toxicity within three years from the start of the industrial pollution, following the fate of all the life-forms in the lake (Monti 1930). Twenty years after that, Baldi (1949) concluded that the lake was still devoid of any recognisable plankton communities, despite some attempts of plankton species to colonise the lake waters. A distinct, though peculiar, colonisation by the phytoplankton took place for the first time in the late 1950s and in the course of the 1960s, after the first, great reduction in copper load of 1957-58. Vollenweider (1963) remarked that, by the end of the 1950s and early 1960s, about thirty algal species were living in the lake. The algal biomass and production were far from negligible in those years, so that Vollenweider (1963) concluded, also on the basis of measurements of primary production with the ${ }^{14} \mathrm{C}$ method, that the lake was showing a trend to a peculiar eutrophication in an unstable environment where the first phase of a chaotic recolonisation was taking place. Among the phytoplankton species, the cyanobacterium Oscillatoria limnetica, at that time classified as Lyngbya limnetica, has been since then a stable, dominant phytoplankton component until the liming was performed, to disappear after 1992.

At the end of the 1960s Bonacina (1970) identified 44 algal species in Lake Orta (26 newly appeared), although only two made up most of the community, i.e. the mentioned O. limnetica and, still more abundant, the chlorophycean Choricystis (formerly Coccomyxa) minor. The latter too disappeared after lake liming, about 20 years later. On the other hand, the diatoms had very much decreased their numbers. In this connection it must be remembered that a lot of small plating factories were being created in the 1960s in the proximity of the lake, usually without any specific treatment. As a result, heavy metals such as chromium and zinc were entering the lake along with copper. It looks reasonable to suppose that the diatoms were strongly affected by the presence of heavy metals in waters where acidity was increasing too. It will be seen that diatoms did not resume an intense growth until the liming intervention concurrently caused a $\mathrm{pH}$ rise and metal subtraction. The behaviour of the diatoms with time was recently described and explained in Lake Orta in a study of sediment cores, by which the very different response of different diatom species or groups of species to the recent pollution, especially by metals, was demonstrated (Ruggiu et al. 1998).

No relevant new facts on the phytoplankton or other biological communities were reported in Lake Orta during the 1970s, a decade in which only some routine 
surveys, and no new investigations, were made on the plankton.

Several papers exist on the long-term history of Lake Orta, some of them including the events which occurred a few years after liming. (see for all Calderoni et al. 1992). In addition to the earlier papers on the phytoplankton, one must mention two paleolimnology works with core samples. The first, extending back to the beginning of the $20^{\text {th }}$ century, is on sub-fossil pigments (Guilizzoni \& Lami 1988), and describes the succession of the main groups of photosynthesisers before and after the pollution of 1926; the second, on cores dating back to about $1600 \mathrm{AD}$, has just been mentioned (Ruggiu et al. 1998).

A few papers exist on the situation of the phytoplankton proper in the 1980s and 1990s. One of these regards an intensive investigation made in the year 1985 in which, beside a detailed account of the phytoplankton dynamics, measurements of primary production were regularly made in Lake Orta (Pizzolon et al. 1992). Other papers describe the phytoplankton in the years 1987 and 1988, just preceding the liming intervention, (Ruggiu \& Morabito 1990) and the situation in 1994, four years after liming (Morabito \& Curradi 1997).

Trends and events in the phytoplankton in the course of the last two decades, from 1984 to the present time, are the subject of this paper. That period was chosen because the frequency of sampling in a central station made it possible a long-term analysis based on a sampling date per month, as was successfully done on the nearby Lago Maggiore (Ruggiu et al. 1998). The years 1987 and 1988 were skipped because of a too small number of samplings, but they have been anyway analysed as regards the phytoplankton assemblage, already described in the paper by Ruggiu \& Morabito (1990). The year 1985 was omitted from the long-term analysis only for species diversity, which was difficult to compare with the other years because of the different sampling designs. The sampling depths $(0-20 \mathrm{~m})$ and the subsequent laboratory methods (phytoplankton countings and identification, chlorophyll and biovolume determinations, etc.) were also the same as in Lago Maggiore. In particular, the phytoplankton were fixed in Lugol's solution and counted with the Utermöhl's method (Lund et al. 1958). The biovolume was estimated from original measurements for the most important species. Chlorophyll- $a$ was determined spectophotometrically on $90 \%$ acetone extracts (Lorenzen 1967) of grinded GF/C filters used for filtering lake water.

The considered phytoplankton characteristics were also the same as in Lago Maggiore, except that biodiversity, evenness and species number were added .

The algal assemblages and their changes with time were analysed in detail by multivariate techniques: the phytoplankton data set was analysed through a cluster analysis applied to a dissimilarity matrix obtained from the calculation of the Bray-Curtis index, as explained in
Salmaso (1996). In a first step the calculation of the distance matrix has been carried out on each yearly data set. The mean density of each cluster has been calculated, obtaining a second data set in which every year was represented by seasonal groups. In this way the whole data set has been reduced to a smaller matrix, making easier the comparison of the seasonal communities from year to year. The seasonal groups identified were named as follows: WI $=$ Winter, W-S $=$ WinterSpring, ESP $=$ Early Spring, $\mathrm{SP}=$ Spring, LSP $=$ Late Spring, ESU $=$ Early Summer, $\mathrm{SU}=$ Summer, LSU $=$ Late Summer $\mathrm{S}-\mathrm{A}=$ Summer-Autumn, EAU = Early Autumn, AU $=$ Autumn and LAU $=$ Late Autumn.

\section{RELATIONSHIPS BETWEEN SOME SYNTHETIC CHARACTERISTICS OF THE PHYTOPLANKTON AND THEIR TIME COURSE}

\subsection{Correlations}

Linear correlations between selected variables are reported in table 1, comprising 144 monthly cases corresponding to 12 years of the 15 years period 19841998. Three years were not considered, for reasons explained in the previous paragraph.

We realise that a linear correlation matrix is the roughest way to demonstrate statistical relations among biological variables, if only because the relations are rarely linear. However, as a first approximation, we are interested not so much on the exact nature of the relationships, often difficult to ascertain, as to establish whether statistical relations exist at all, and in that case which is the sign. Postponing to a following paragraph an examination of the variations with time, we note from table 1 that the variables expressing algal amount, i.e. N, BV and Chl, are positively correlated, just as the variables defining diversity, i.e. H, Spp and J. On the other hand, each variable from one group is negatively correlated with each other variable from the second group. We anticipate in this connection that this feature cannot be generalised nor does represent any ecological rule. In fact, we can see no a priori reason why algal diversity should be inversely correlated with total phytoplankton biovolume, except maybe in extreme cases of pollution or eutrophication where one or a few species are favoured. We shall see that in Lake Orta this and other phenomena are the result of the peculiar history of the lake, with his long-term industrial pollution, the large-scale liming, the community adaptations in the following years.

Scatterplots of some of the most important relations between two variables are reported in figure 1, with some statistical curve fittings also shown. The purpose was to show the actual point scattering, and also to get an idea of the respective closeness or distance from linearity in relations which, it must be remembered, have a highly significant correlation coefficient anyway ( $\mathrm{P}<0.001)$. A least squares fitting was made, except for $\mathrm{H}$ vs $\mathrm{J}$ (lower left), where the linearity was unmistake- 
Tab. 1. Correlations between phytoplankton variables. Marked correlations are significant at $\mathrm{p}<0.001$. Time period 1984-1998, with the years 1985, 1987 and 1988 skipped for insufficiency of data; $\mathrm{n}=144$ (monthly data). $\mathrm{N}=$ abundance; $\mathrm{BV}=$ total biovolume; $\mathrm{Chl}=$ chlorophyll- $a$ concentration; Size = average cell size; $\mathrm{H}=$ Shannon diversity; $\mathrm{Spp}=$ species number; $\mathrm{J}=$ evenness.

\begin{tabular}{lcccccccc}
\hline Variable & Month & $\mathrm{N}$ & $\mathrm{BV}$ & $\mathrm{Chl}$ & Size & $\mathrm{H}$ & $\mathrm{Spp}$ & $\mathrm{J}$ \\
\hline Month & 1.00 & & & & & & & \\
N & $-.48^{*}$ & 1.00 & & & & & & \\
BV & $-.25^{*}$ & $.49^{*}$ & 1.00 & & & & & \\
Chl & $-.40^{*}$ & $.52^{*}$ & $.64^{*}$ & 1.00 & & & & \\
Size & $.29^{*}$ & $-.32^{*}$ & $.35^{*}$ & .19 & 1.00 & & & \\
H & $.36^{*}$ & $-.34^{*}$ & $-.55^{*}$ & $-.39^{*}$ & $-.22^{*}$ & 1.00 & & \\
Spp & $.50^{*}$ & $-.38^{*}$ & $-.30^{*}$ & $-.23^{*}$ & $.26^{*}$ & $.59^{*}$ & 1.00 & \\
J & $.32^{*}$ & $-.32^{*}$ & $-.53^{*}$ & $-.31^{*}$ & $-.22^{*}$ & $.94^{*}$ & $.50^{*}$ & 1.00 \\
\hline
\end{tabular}
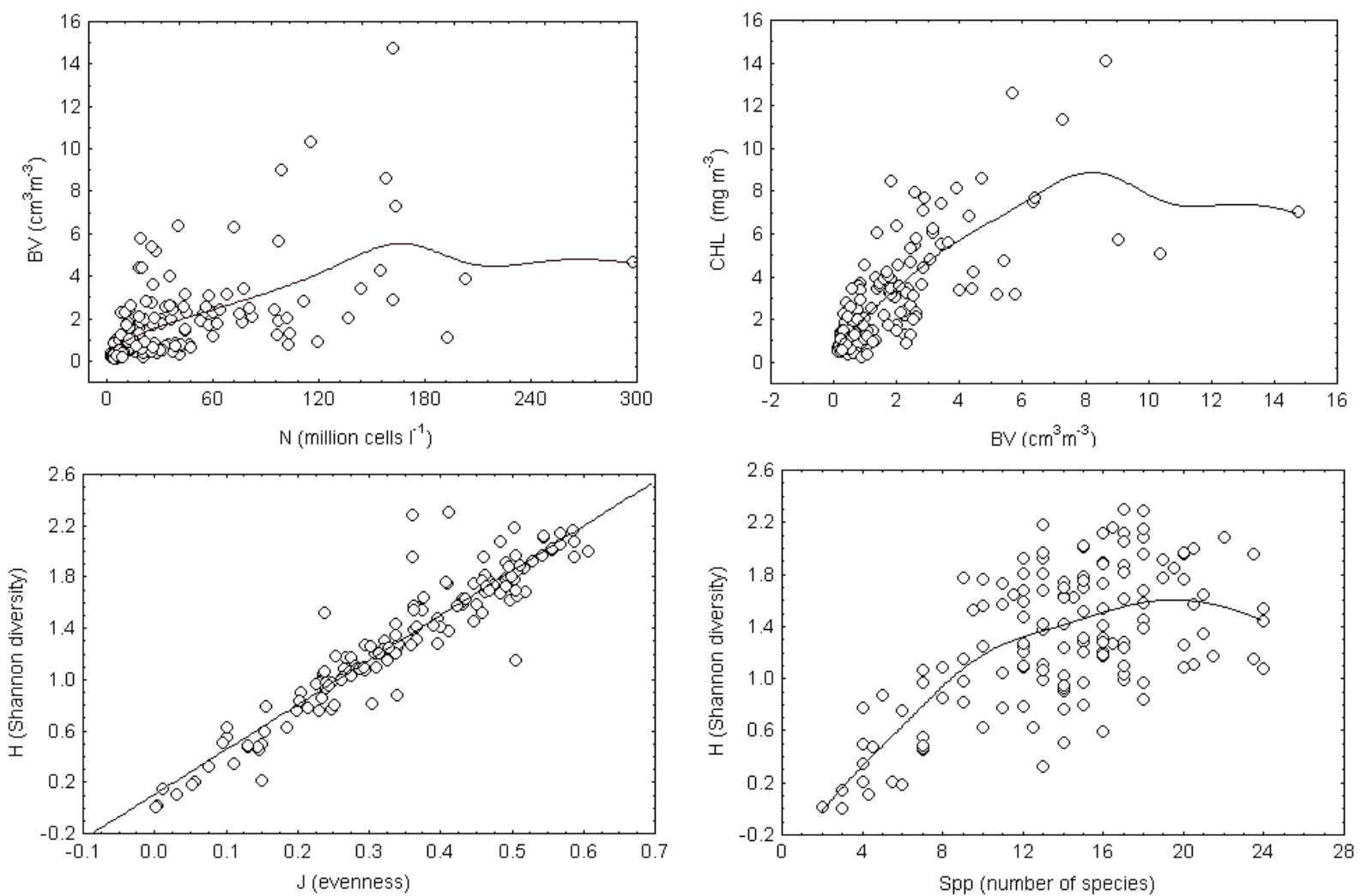

Fig. 1. Scatterplots of the pairs of variables BV-N (upper left), CHL-BV (upper right), H-J (lower left) and H-Spp (lower right). The curves are least-squares fitted, except for the H-J scatterplot (linearly fitted).

able $(\mathrm{r}=0.94)$. For the relation $\mathrm{H}$ vs Spp (lower right, $\mathrm{r}$ $=0.50)$, the resulting curve resembles a negative exponential. We can conclude from these curves that diversity is linearly determined in a very strict way by evenness; it also strongly depends on species number, linearly at first, while above a certain number it begins to flatten and finally possibly to slope down.

The upper panel of figure 1 depicts the scattering and least squares curve fitting for the relations BV-N and CHL-BV respectively. In these cases most points originate fitted curves which are reasonably close to linearity. However, the curves show an inflection starting at a density of about 160 million cells $1^{-1}$ (left) and at a biovolume of about $8 \mathrm{~cm}^{3} \mathrm{~m}^{-3}$ (right), respectively. The points beyond these limits are very few; however, they hint at a flattening of the curves. For the BV-N relationship this means that above the said limit of $\mathrm{N}$ the biovolume does not increase simply because the average cell size gets smaller, a fact which actually happens in Lake Orta and is revealed by the inverse relationship between $\mathrm{N}$ and Size ( $\mathrm{r}=-0.32$, Tab. 1). The interpretation of the right-end curve is not so straight, but probably the flattening of the curve (very few points!) has to do with different chlorophyll content in different algal taxa. 


\subsection{Time series}

In table 1, time has been treated as a variable (month) with the same status as the others. Consequently, a standard set of correlations has been calculated, indicating an overall trend of the single biological variables over the 15 year period. Based on the correlation coefficients, this long-term trend is negative for the variables indicating algal amount $(\mathrm{N}, \mathrm{BV}$ and $\mathrm{Chl})$, and positive for those defining diversity (H, Spp and J). Also average cell size seem to increase on the longterm. However, this kind of information is too simplistic, as the variations with time can be very large and the trends may even be reversed in particular periods. Much additional information can be gained from figures representing the time course of the variables, as done in figures 2 and 3, where a least squares curve fitting is also reported.
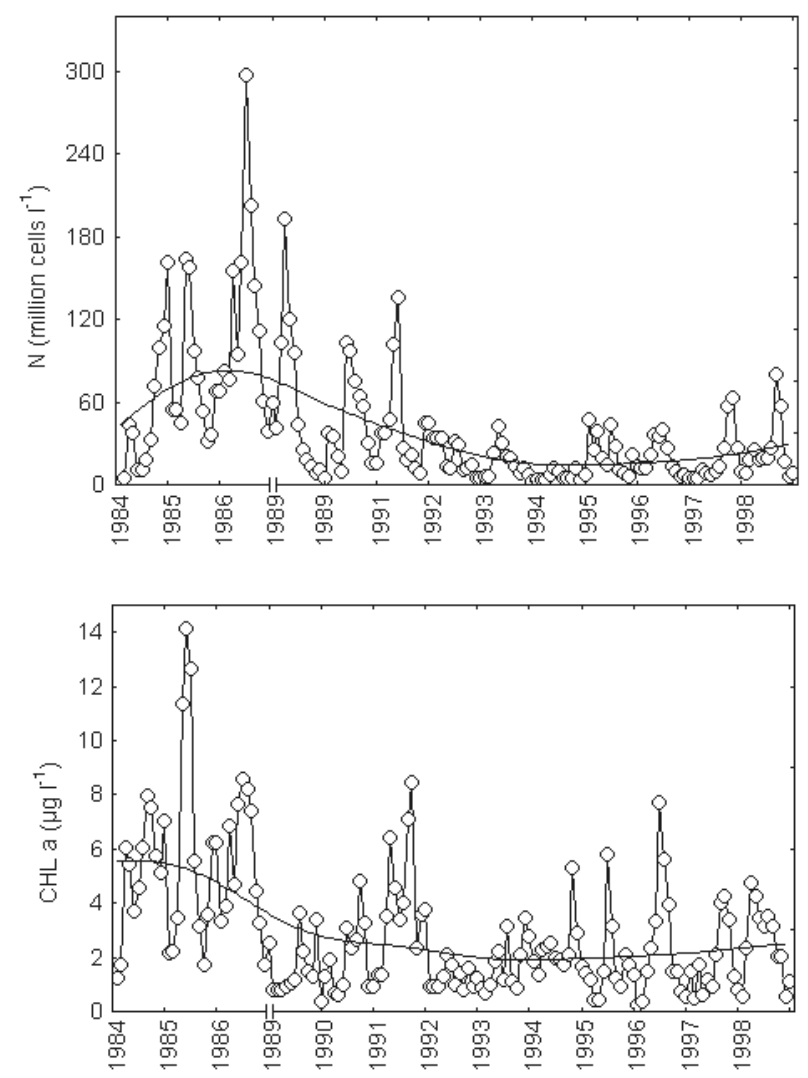

1989-1990, and (3) the remaining period until 1998, the last year for which detailed data are available.

The pollution abatement of the early 1980 s was of great consequence. Bottom fauna reappeared after decades and the zooplankton was enriched (Bonacina et al. 1988). A study of phytoplankton and primary production demonstrated that by 1985 total density, biovolume and number of species was increasing, together with significant changes in species composition (Pizzolon et al. 1992). In the years immediately preceding liming the variables $\mathrm{N}, \mathrm{BV}$ and $\mathrm{Chl}$ were at their maximum values over the entire period (Fig. 2). For these variables liming was another turning point, in that they started to show sharply decreasing values until 1993-1994, and are slowly increasing since then. A different trend is shown by the average cell size: it was sharply decreasing before liming, due to changes in species composition (Pizzolon et al. 1992); it increased sharply with
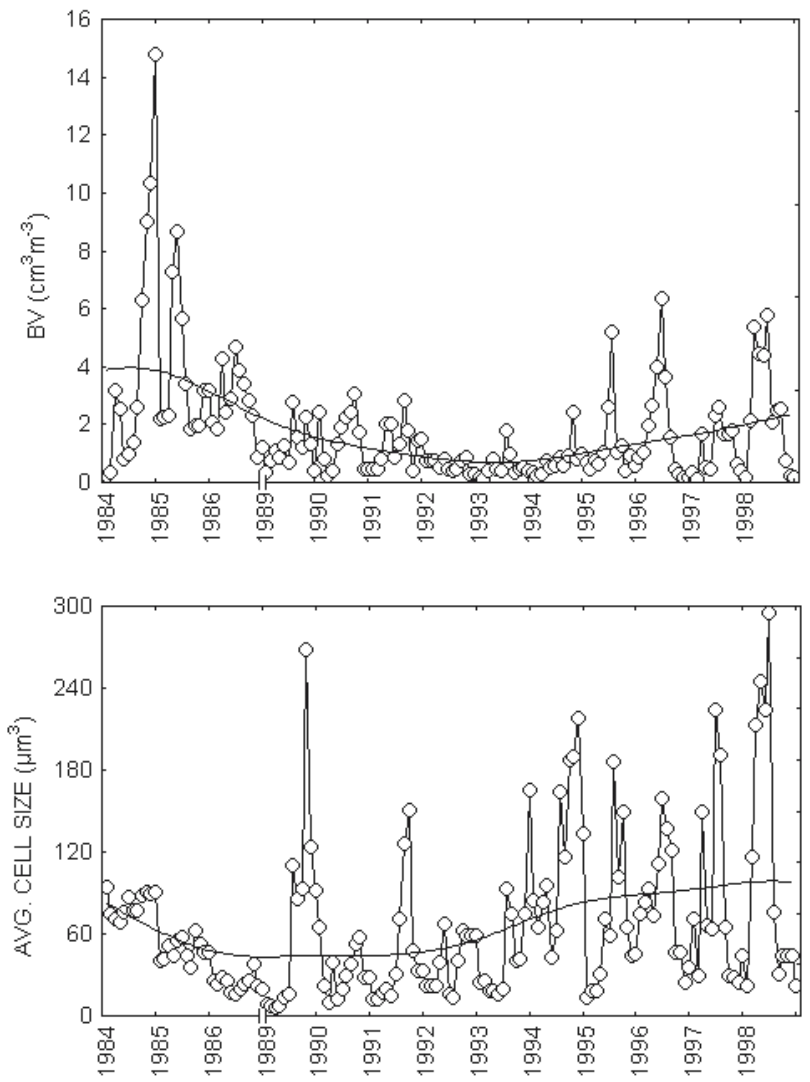

Fig. 2. Time courses (1984-1998) of phytoplankton abundance N, biovolume (BV), chlorophyll- $a$ (CHL- $a$ ), and average cell size. The curves are least-squares fitted.

The curves represent actual variations on a monthly scale. These variations must be seen against the background of some larger scale situations, or events, characterising different subperiods, i.e. (1) 1984-1988, preceding the liming intervention but following a big ammonia and copper abatement system adopted by the main polluter in 1981-1982; (2) the liming intervention, liming and kept increasing, on average and with wide fluctuations, until the present time.

A slightly different time course is that of the variables defining the overall species structure (Fig. 3). Starting from very low values in 1984 due to a community still characterised by a very few species, the variables showed regularly and steeply increasing values 

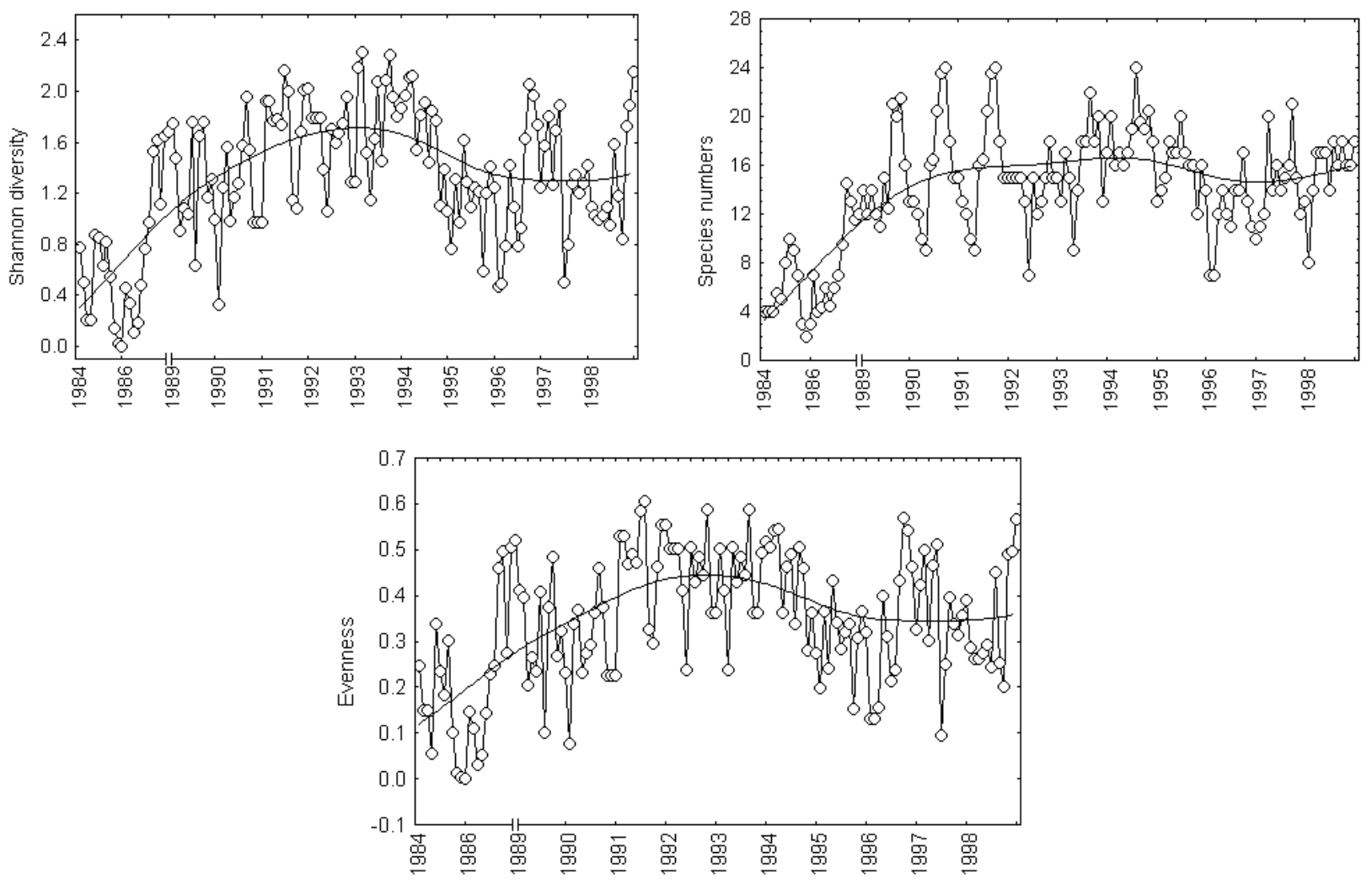

Fig. 3. Time courses (1984-1998) of phytoplankton diversity, species number, and evenness. The curves are least-squares fitted.

until 1993-1994: look for instance at the number of species, which raised from 2-10 per sample in 1984 to ranges of 10-24 in the years immediately following liming. A flattening or a slow decrease was apparent after 1994, and is followed by signs of a possible new increase in the last two years.

\section{INTERANNUAL AND SEASONAL EVOLUTION OF ALGAL ASSEMBLAGES}

\subsection{Abundance}

The cluster analysis of the abundance data set gave the dendrogram reported in figure 4. At the highest hierarchical level two large clusters are clearly separated. The first one includes all the samples collected during the period 1984-1988 (summer 1987 excluded), whereas to the second belong the remaining samples (19891998). This kind of clustering points out two well distinct phases of the long-term evolution of the phytoplankton assemblage in L. Orta: the first one (1984-'88) typified by an extremely simplified community, largely dominated by Choricystis minor v. gallica and Scenedesmus cfr. armatus, the second characterised by the decline of these two chlorophytes and the appearance of new species, brought about by the chemical and biological modifications occurred in the lake after the liming intervention. A clustering at lower linkage distance allows to analyse the differences between the samples collected in each of the two phases previously identified.

\subsubsection{First period (1984-1988)}

Few comments can be done as regards this time period: two species, Choricystis minor v. gallica and Scenedesmus cfr. armatus, dominated the algal assemblages from 1984 until 1988 with variable importance. The samples belonging to this time period are simply separated according to their respective dominance. In particular, three different clusters were obtained (linkage distance 0.6): the larger one is characterised by the dominance of Choricystis minor v. gallica together with Oscillatoria limnetica, the intermediate cluster (AU84, WI85, and SU88) by the absolute prevalence of Scenedesmus cfr. armatus. The smaller one includes only the sample W188, characterised by the decline of Scenedesmus cfr. armatus and the development of other species (Dinobryon sertularia, Chlamydomonas gloeophila, Cryptomonas erosa, Oocystis lacustris) coupled with an increase of the community diversity.

\subsubsection{Second period (1989-1998)}

This large cluster can be subdivided at a linkage distance of 0.8 in two smaller groups; the first including 


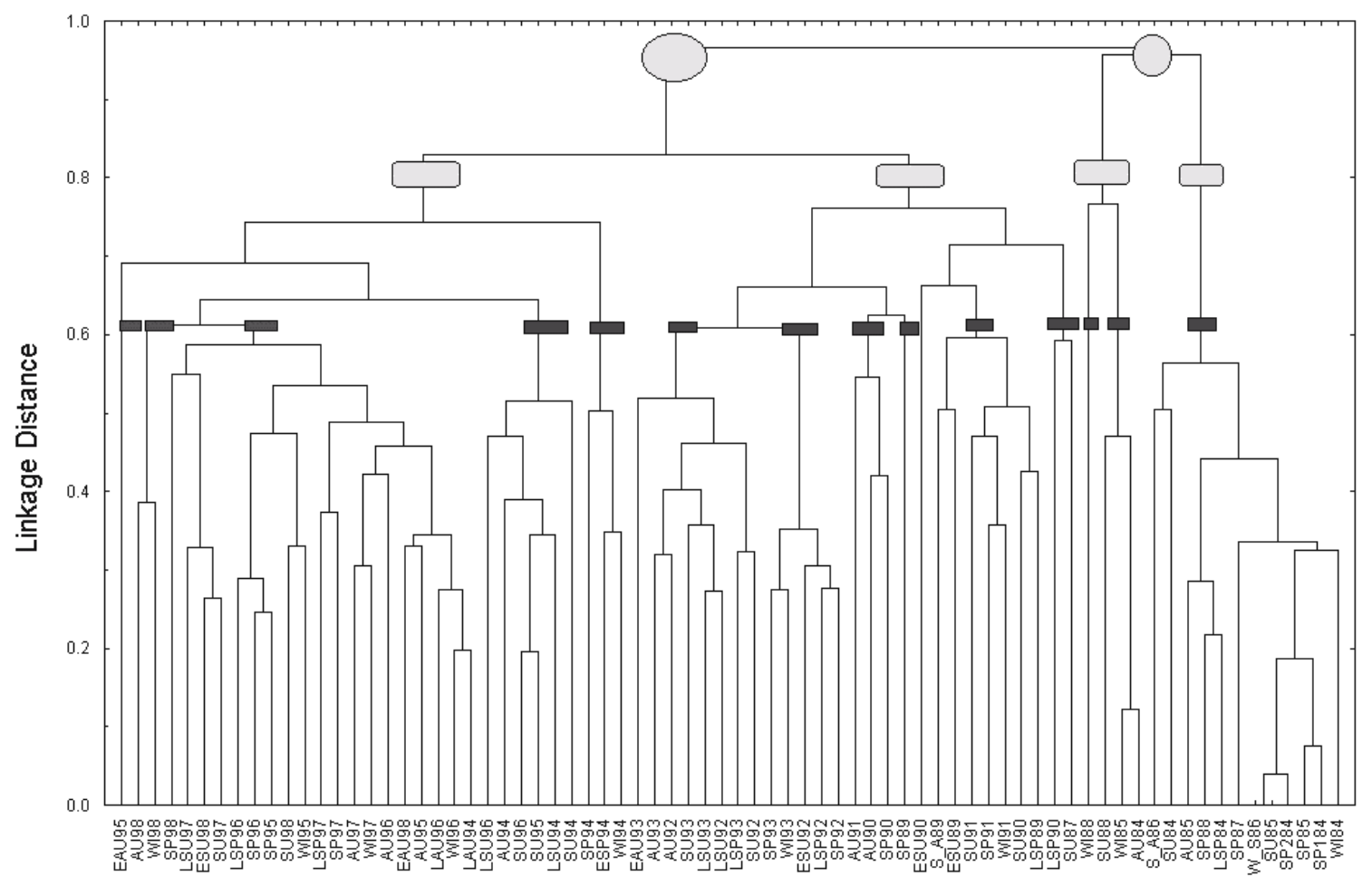

Fig. 4. Clustering of the abundance data set. The hierarchical linkage levels are separated by grey ellipses (first level), grey squares (second level) and black squares (third level). The codes of the samples are explained in the text.

the samples of the period 1989-1993, the second those collected between 1994 and 1998. For each time period we can identify a "distinctive species", namely a species characterising the algal assemblage during the whole period, being continuously present with high numbers. Between 1989 and 1993 the "distinctive species" was Stichococcus minutissimus, replaced by Synechococcus $\mathrm{sp}$. in the following four years. The numerical dominance shift from chlorophytes to blue-green algae described in figure 5 can be mainly explained by the succession of these two taxa.

The samples collected during early summer 1989, immediately after the beginning of the liming intervention, and during early summer 1990, when the liming activity was still in progress, can be distinguished because of the bloom of Achnanthes minutissima. However, looking at the time series starting from spring 1989 until autumn 1993 (Fig. 5), it is clear that the sudden change of the phytoplankton composition, due to the massive development of this diatom, was a short break related to carbonate addition: once stopped this intervention, the species assemblage reverted towards a structure similar to that of spring 1989, characterised by the dominance of Stichococcus minutissimus.

Since 1992 Synechococcus sp. occupied a relevant place inside the algal assemblage, replacing Oscillatoria limnetica as the dominant blue-green (Fig. 5): however a shift in the dominance was evident starting 1994 on- wards, due to the increasing importance of Synechococcus sp. Since spring 1996 the increasing abundance of the diatoms, mainly Synedra tenera, is clearly pointed out by the clustering results (Fig. 5). Their growing importance from year to year and the increasing diversity of the group are perhaps the most important clue of the changes experienced by the phytoplankton assemblage.

At a lower hierarchical level (linkage distance 0.6) smaller clusters can be identified, indicating the importance reached during shorter time periods by some species, such as Oscillatoria limnetica in spring and summer 1990-'91, Monoraphidium komarkovae in winter and spring 1992-'93, Scenedesmus linearis in summer 1992 and 1993, Scourfieldia cordiformis in spring 1994, cfr. Westella botryoides during summer and autumn 1994. The most recent time period (1995-1998) was characterised by the numerical dominance of Synechococcus sp. in every season: during spring and summer 1995-'96 Synedra tenera reached sometimes significant densities.

\subsection{Biovolume}

\subsubsection{First period (1984-spring 1989)}

The dendrogram reported in figure 6 results from the cluster analysis carried out on the biovolume data set. At a linkage distance of about 0.95 a first separation of the samples in three cluster was obtained: the smaller 


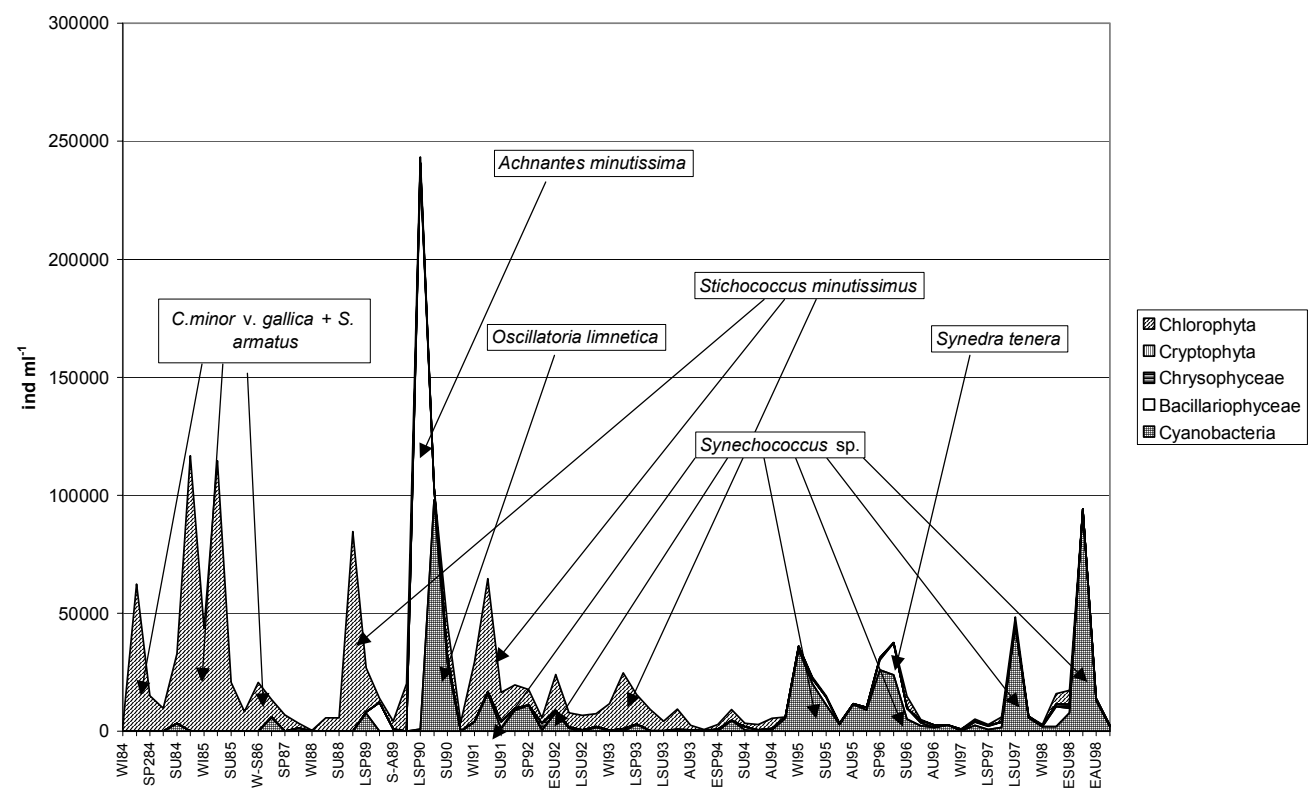

Fig. 5. Long-term evolution of the phytoplankton abundance in Lake Orta. The dominant species in each algal group are indicated.

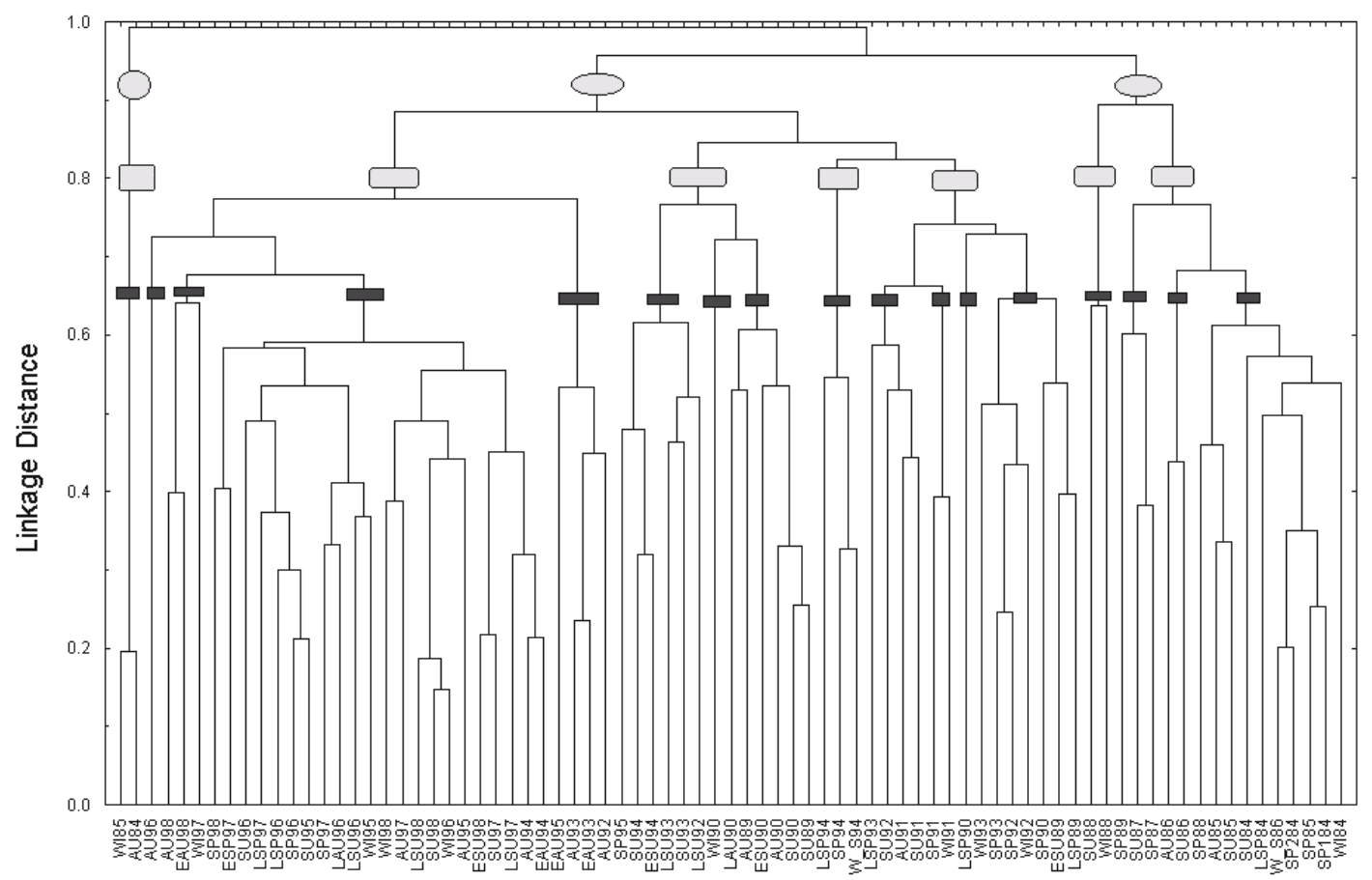

Fig. 6. Clustering of the biovolume data set. The hierarchical linkage levels are separated by grey ellipses (first level), grey squares (second level) and black squares (third level). The codes of the samples are explained in the text.

cluster includes only the autumn '84 and winter ' 85 samples, in which a single species (Scenedesmus cfr. armatus) made up more than $90 \%$ of the total biovolume. The remaining samples collected between winter 1984 and spring 1989 are included in a different cluster: the "distinctive species" of this time period is Choricystis minor v. gallica, even though its abundance shows a decline toward the end of the 1980s and the alga is sometimes completely lacking during the seasonal succession. This is probably the reason for the separation (at 0.8 linkage distance) of the samples collected during winter and summer 1988, in which Choricystis minor v. gallica was not found. 
Different unidentified Chlamydomonas species are also important during these years, in particular during spring and summer 1987 and spring 1989: the respective samples are separated at a linkage distance of 0.65 . At the same hierarchical level the samples of summer and autumn 1986 can be distinguished due to the dominance of Chlorella sp.

\subsubsection{Second period (late spring 1989-1998)}

The third major cluster includes the samples collected in the decade 1989-1998. A further separation at a lower level (linkage distance 0.9) suggests the division of this time period in two different phases, the first from late spring 1989 to spring 1995, the second from summer '95 to autumn ' 98 . It should be noted that the autumnal samples of the years 1992, 1993 and 1994 belong to this second cluster. Most of the winter and spring samples collected from 1989 to the 1993 are joined together at a linkage distance less than 0.8. Many different species typify this group of samples (Achnanthes minutissima, Cosmarium tenue, Oscillatoria limnetica, Monoraphidium komarkovae, Synechococcus sp.) but two can be identified as "distinctive species", i.e. Dinobryon sertularia and Stichococcus minutissimus. The liming affected the species assemblage during summer 1989 and 1990, favouring the dominance of Achnanthes minutissima: the effect was acute, but shortlived, as already observed for the abundance data set.

The dominance of some unidentified chlorophytes characterised the samples gathered during spring 1994, separated at a 0.8 linkage distance. At the same distance we can also identify a cluster including the summer and autumn samples of the period 1989-1994 (excluding autumn '92, '93 and '94): Westella botryoides and Synedra tenera can be identified as "distinctive species" of these seasons.

The last large cluster (linkage distance 0.8) groups the samples collected from autumn 1992 to autumn 1998, regardless of the season. This time period is characterised by three "distinctive species", Synedra tenera, Rhizosolenia eriensis and Synechococcus sp.: the diatoms dominated mostly during spring and summer, whereas the blue-green was important in every season.

At a lower hierarchical level (linkage distance 0.65) we can identify two smaller clusters, the first including the samples collected during autumn '92, '93 and '95, characterised by the dominance of Cryptomonas ( $C$. erosa, $C$. erosa v. reflexa), the second made up by the winter '97 and autumn '98 samples, in which Rhodomonas minuta was particularly important.

The analysis of the biovolume data set clearly points out (Fig. 7) the dominance shift from the chlorophytes (period 1984-1992) to the diatoms (period 1994-1998), separated by an intermediate phase, during which the community biovolume was quite low: in this period (1992-1994) the chrysophytes (mainly Dinobryon sertularia) were particularly important and replaced the diatoms during the spring phase of the seasonal succession.

\section{DISCUSSION}

When, by the end of the 1980s, a large-scale liming operation was decided, and the funds raised, those of us who were involved were fairly sure that, sooner or later, the lake communities would adapt to the likely improved chemical conditions to reach a status similar to that of other deep subalpine lakes. The possibility existed that so sudden and big an action would be stressful to organisms adapted to a very different, though abnormal, environment and cause a generalised species collapse as a first result. This prospect was particularly worrying in the light of an existing, strong opposition of environmentalist groups to such an uncontrolled undertaking on a large ecosystem. It was our luck, and an instructive scientific result, that no collapse occurred. Compared with the two years prior to liming, in the course of the years 1989 and 199017 algal species or genera disappeared, 18 survived and 41 new species appeared (Tondina 1992; Calderoni et al. 1992; Morabito $\&$ Curradi 1997). As a result, the number of species was more than doubled.

Just as striking as the increase in diversity was the sudden development of the diatoms, which were reduced to rare occurrences in Lake Orta as acidity, and the continuing metal pollution, for which the diatoms were extremely sensible (Ruggiu et al. 1998) progressed in the previous two decades. However, as pointed out by Hörnström et al. (1993) the recovery of a lake after liming is a slow process and the recolonization usually takes some years. In fact only in the last few years (1995-1998) clear signs of recovery towards a phytoplankton assemblage more typical of the deep subalpine lakes appeared. Among others, the invasion of the groups Cyanobacteria and Bacillariophyceae, an event commonly recorded in the limed lakes (Hörnström et al. 1993). These are usually the two most important groups in the deep and large Italian lakes (i.e. Ruggiu et al. 1991, 1992, Polli \& Simona 1992, Cordella \& Salmaso 1993).

Noticeable is the reduction of the chlorophytes, which could be related to the continuous decrease of the metals concentration, in particular of $\mathrm{Cu}$ and $\mathrm{Al}$, whose peak values at spring overturn diminished from $20 \mathrm{~g} \mathrm{~g}^{-1}$ in 1993 to 4 in 1999 and from $60 \mu \mathrm{g} \mathrm{l}^{-1}$ in 1993 to 6 in 1999 respectively (Calderoni \& Tartari 2001). In fact it has been shown that the resistance to metals toxicity is a phenomenon especially occurring among the green algae (Takamura et al. 1989), whose competitive advantage in Lake Orta could have been reduced by the decreased toxicity of the water.

Even the dominance of the blue-green alga Synechococcus sp. can indicate an improvement of the water quality. The dynamics of this group in Lake Orta is certainly peculiar and seems to contradict the hypothe- 


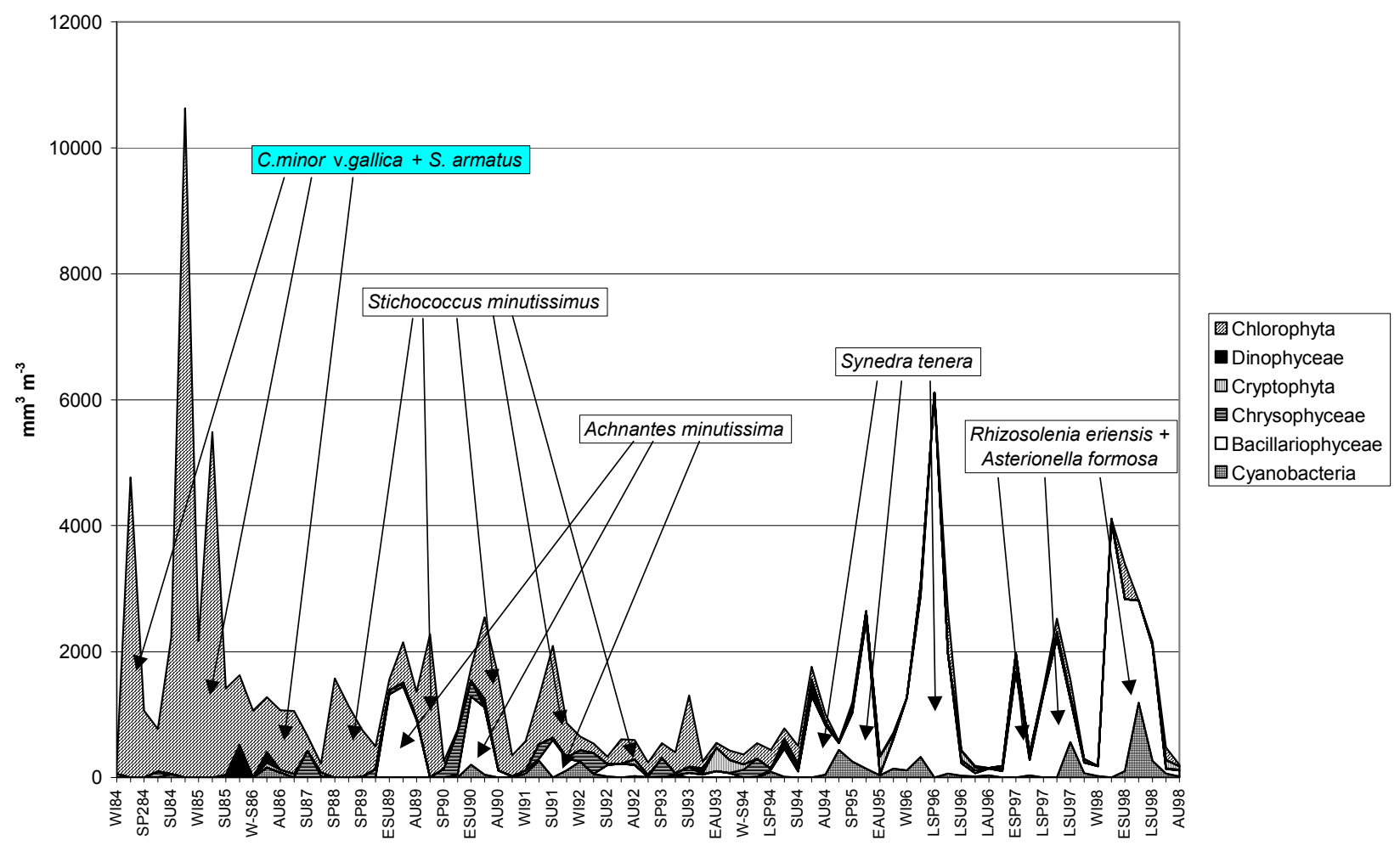

Fig. 7. Long-term evolution of the phytoplankton biovolume in Lake Orta. The dominant species in each algal group are indicated.

ses by Blomquist et al. (1994) and Anderson et al. (1997) that cyanobacterial dominance is controlled by the availability of ammonium nitrogen: in fact, Planktothrix rubescens (formerly Oscillatoria) was dominating the Lake Orta phytoplankton community for more than 30 years (1949-1981), in spite of the accumulation of nitrate in the lake (exceeding $5 \mathrm{mg} \mathrm{l}^{-1}$ in 1975), brought about by the nitrification process. On the other side, Cyanobacteria disappeared during the 1980s, when the nitrification was inhibited by the strong acidity and the ammonium concentration was increasing, and reappeared after liming, when the nitrification started again and the ammonium was declining. Perhaps the acidic conditions and the metal pollution played a more important role than the ammonium-nitrate dynamics, considering that Cyanobacteria are more sensitive than other algae to trace metals (Takamura et al. 1989).

A further sign of recovery is given by the dynamics of the diatoms: after their disappearance in the 1930s, just after the liming an ephemeral "outburst" of Achnanthes minutissima was recorded (Calderoni et al. 1992). It is known from literature (Anderson et al. 1997) that A. minutissima, due to its ubiquitous distribution and the large availability of inocula, is often a pioneer species in limed lakes and responds very quickly to liming when the $\mathrm{pH}$ raises to a level that it can tolerate. Anyway, since 1994 the diatoms are always present in the phytoplankton community with in- creasing importance and diversity. Moreover, diatom growth, which in 1994 took place during the summer period, when the concentration of trace metals was decreasing after the peak occurring at spring overturn (Morabito \& Curradi 1997), now often starts during spring, as usual in other subalpine lakes (i.e. Salmaso 1996; Ruggiu et al. 1998). The composition of the diatom assemblage, however, still mirrors the presence of toxic pollutants in the lake: as reported by Deniseger et al. (1990) the two dominant taxa (Synedra tenera and Rhizosolenia eriensis) seem to be more tolerant than other diatoms to moderate concentrations of toxic metals.

A certain interannual variability inside the dominant species assemblage is however still present, meaning that the phytoplankton community is still evolving from year to year. In spite of the heavy metals loading, whose negative effects are now probably buffered by the actual $\mathrm{pH}$ values of the lake water, the chemical environment should be now suitable for the living of most of the algal species typical of the deep subalpine lakes. The main abiotic factor that in the next years could play a major role in modifying the species assemblage is probably the phosphorus supply: according to some preliminary investigations (Calderoni et al. 1997) the annual phosphorus load from the basin is very high, even though the in-lake concentration remains very low. At present the physico-chemical mechanisms, which, 
during and after the liming, contributed to remove the phosphorus by precipitation, should be greatly reduced, but the possible new mechanisms involved in the phosphorus dynamics are still unknown (Calderoni, pers. comm.). A better understanding of these mechanisms represent the basis to make reliable hypotheses about the evolution of the phytoplankton assemblage, whereas the reduction and controlling of the nutrients and heavy metals loads appear essential to ensure the complete recovery of the primary producers community.

\section{REFERENCES}

Anderson, N.J., P. Blomquist \& I. Renberg. 1997. An experimental and palaeoecological study of algal responses to lake acidification and liming in three central Swedish lakes. Eur. J. Phycol., 32: 35-48.

Baldi, E. 1949. Il Lago d'Orta, suo declino biologico e condizioni attuali. Mem. Ist. ital. Idrobiol., 5: 145-188.

Blomqvist, P., A. Pettersson \& P. Hyenstrand. 1994. Ammonium-nitrogen: A key regulatory factor causing dominance of non-nitrogen-fixing cyanobacteria in aquatic systems. Arch. Hydrobiol., 132: 141-164.

Bonacina, C. 1970. Il Lago d'Orta: ulteriore evoluzione della situazione chimica e della struttura della biocenosi planctonica. Mem. Ist. ital. Idrobiol., 26: 141-204.

Bonacina, C., G. Bonomi, L. Barbanti, R. Mosello \& D. Ruggiu. 1988. Recovery of an industrially acidified, ammonium and heavy metals polluted lake (Lake Orta, N. Italy) due to the adoption of treatment plants. Verh. int. Ver. Limnol., 23: 535-544.

Bonardi, E. 1885. Sulle Diatomee del Lago d'Orta. Boll. Scientifico, $7: 1-8$

Calderoni, A. \& G.A. Tartari. 2001. Evolution of the water chemistry of Lake Orta after liming. J. Limnol., 60(1): 6978.

Calderoni, A., R. de Bernardi \& R. Mosello. 1997. Le fasi recenti del recupero del Lago d'Orta. In: R. Mosello \& G.Giussani (Eds), Evoluzione recente della qualità delle acque dei laghi profondi sudalpini. Documenta Ist. ital. Idrobiol., 61: 55-72.

Calderoni, A., R. Mosello \& D. Ruggiu. 1992. Sixty years of limnology in Lago d'Orta: a case history of recovery from heavy pollution. Mem. Ist. ital. Idrobiol., 50: 201-223.

Cordella, P. \& N. Salmaso. 1993. Phytoplankton communities in the southern basin of Lake Garda, Italy. Verh. int. Ver. Limnol., 25: 754-761.

Deniseger, J., L.J. Erickson, A. Austin, M. Roch \& M.J.R. Clark. 1990. The effects of decreasing heavy metal concentrations on the biota of Buttle Lake, Vancouver Island, British Columbia. Wat. Res., 24: 403-416.

Giaj Levra, P. 1925. Diatomee del Lago d'Orta. Atti Soc. Ligustica Sci. Lett., N.S., 5: 66-82.

Guilizzoni, P. \& A. Lami. 1988. Sub -fossil pigments as a guide to the phytoplankton history of the acidified Lake Orta (N. Italy). Verh. int. Ver. Limnol., 23: 874-879.

Hörnström, E., C. Ekström, E. Fröberg \& J. Ek. 1993. Plankton and chemical-physical development in six Swedish west coast lakes under acidic and limed conditions. Can. J. Fish. aquat. Sci., 50: 688-702.
Lund, J.W.G., C. Kipling \& E.D. Le Cren. 1958. The inverted microscope method of estimating algal numbers and the statistical basis of estimations by counting. Hydrobiologia, 11: $143-170$.

Lorenzen, C.J. 1967. Determination of chlorophyll and phaeopigments: spectrophotometric equations. Limnol. Oceanogr., 12: 343-346.

Monti, R. 1930. La graduale estinzione della vita nel Lago d'Orta. Ist. Lomb. Sc. Lett., 58: 1-22.

Morabito, G. \& M. Curradi. 1997. Phytoplankton community structure of a deep subalpine Italian lake (Lake Orta, N.Italy) four years after the recovery from acidification by liming. Int. Rev. Ges. Hydrobiol., 82: 487-506.

Parona, C. 1880. Prime ricerche intorno ai protisti del Lago d'Orta. Boll. Scientifico, 2.

Pizzolon, L., D. Ruggiu \& G. Morabito. 1992. Primary production and phytoplankton communities in the acidified Lake Orta (N. Italy) after the removal of ammonia pollution. Mem. Ist. ital. Idrobiol., 51: 29-52.

Polli, B. \& M. Simona. 1992. Qualitative and quantitative aspects of the evolution of the planktonic populations in Lake Lugano. In: A. Barbieri \& B. Polli (Eds), Limnological Aspects and Management of Lago di Lugano. Aquat. Sci., 54: 303-320.

Ruggiu, D., A. Luglié, A. Cattaneo \& P. Panzani. 1998. Paleoecological evidence for diatom response to metal pollution in Lake Orta (N. Italy). J. Paleolimnol., 20: 333-345.

Ruggiu, D., G. Morabito, P. Panzani \& A. Pugnetti. 1998. Trends and relations among basic phytoplankton characteristics in the course of the long-term oligotrophication of Lake Maggiore (Italy). Hydrobiologia, 369/370: 243-257.

Ruggiu, D., P. Panzani \& G. Morabito. 1991. Indagini sul fitoplancton. In: CNR Istituto Italiano di Idrobiologia (Ed.), Ricerche sull'evoluzione del Lago Maggiore. Aspetti limnologici. Programma quinquennale 1988-1992 (Campagna 1990). Commissione internazionale per la protezione delle acque italo-svizzere): 78-83.

Ruggiu, D., P. Panzani \& G. Morabito. 1992. Indagini sul fitoplancton. In: CNR Istituto Italiano di Idrobiologia (Ed.), Ricerche sull'evoluzione del Lago Maggiore. Aspetti limnologici. Programma quinquennale 1988-1992 (Campagna 1991). Commissione internazionale per la protezione delle acque italo-svizzere): 46-48.

Ruggiu, D. \& G. Morabito. 1990. Studi sul fitoplancton effettuati negli anni 1987 e 1988, nel quadro dell'evoluzione a lungo termine del Lago d'Orta. Documenta Ist. ital. Idrobiol., 28: 89-100.

Salmaso, N. 1996. Seasonal variation in the composition and rate of change of the phytoplankton community in a deep subalpine lake (Lake Garda, Northern Italy). An application of nonmetric multidimensional scaling and cluster analysis. Hydrobiologia, 337: 49-68.

Takamura, N., F. Kasai \& M.M. Watanabe. 1989. Effects of $\mathrm{Cu}, \mathrm{Cd}$ and $\mathrm{Zn}$ on photosynthesis of freshwater benthic algae. J. Appl. Phycol., 1: 39-52.

Tondina, A. 1992. Studi sulla dinamica del fitoplancton del Lago d'Orta in relazione ad un intervento di liming su larga scala. Doctoral thesis, University of Parma: $185 \mathrm{pp}$.

Vollenweider, R.A. 1963. Studi sulla situazione attuale del regime chimico e biologico del Lago d'Orta. Mem. Ist. ital. Idrobiol., 16: 21-125. 